\title{
October 1974
}

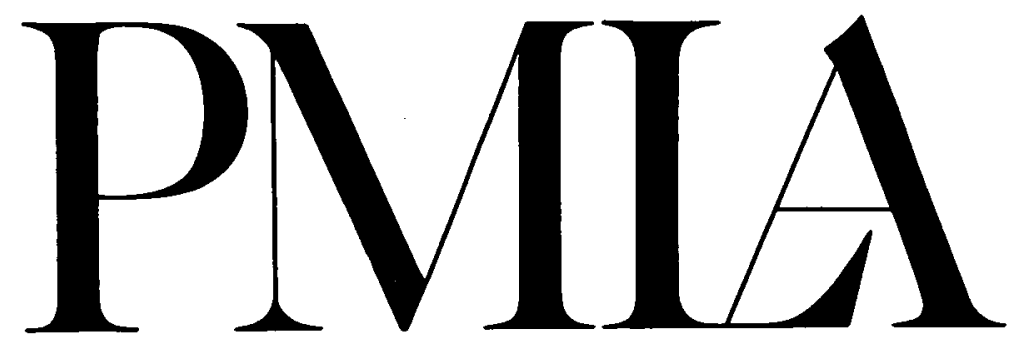

\section{Publications of the}

Modern Language Association of America 


\section{The Modern Language Association of America ORGANIZED 1883 \\ INCORPORATED 1900}

\section{OFFICERS FOR THE YEAR 1974}

President: JOHN HURT FISHER, University of Tennessee

First Vice-President: GermaINE BRÉE, Wake Forest University

Second Vice-President: NORTHROP FRYE, University of Toronto

Executive Secretary and Treasurer: WILLIAM D. SCHAEFER

\section{EXECUTIVE COUNCIL}

For the term ending 31 December 1974

Claudio Guillén, Univ. of California, San Diego

Margaret McKenzie, Vassar Coll.

RoberTa SalPer, State Univ. of New York, Old Westbury

For the term ending 31 December 1975

John C. Gerber, Univ. of Iowa

Olga M. Ragusa, Columbia Univ.

Helen Hennessy Vendler, Boston Univ.
For the term ending 31 December 1976

WAYNe C. BOOTH, Univ. of Chicago

Geneviève Delattre, Univ. of California, Santa Barbara

JOAN WEBBER, Univ. of Washington

For the term ending 31 December 1977

Mary Ann Caws, Hunter Coll. of the City Univ. of New York

Stanley B. Greenfield, Univ. of Oregon

KaTHLeEN Williams, Univ. of California, Riverside

\section{TRUSTEES OF INVESTED FUNDS}

\section{Gordon N. RaY, Guggenheim Foundation, Frederick Burkhardt, Bennington, Ver- Managing Trustee mont}

C. WALler BarretT, Charlottesville, Va.

$P M L A$ is issued six times a year, in January, March, May, September, October, and November, by the Modern Language Association of America, 62 Fifth Avenue, New York, New York 10011. Membership is open to those persons who are professionally interested in the modern languages and literatures. Annual dues, which include subscription to $P M L A$, are based on members' salaries and are graduated as follows: student members, $\$ 10$; unemployed regular members, $\$ 10$; regular members (first two years), $\$ 20$; regular members (salary under $\$ 12,000), \$ 25$; regular members (salary $\$ 12,000-18,000$ ), $\$ 30$; regular members (salary over $\$ 18,000$ ), $\$ 35$; joint members (with only 1 subscription to $P M L A$ ), $\$ 45$; foreign members, same as regular members.

The subscription price of $P M L A$ for libraries and other institutions is $\$ 25$. A subscription including a bound volume at the end of the year is $\$ 40$, domestic and foreign. Agents deduct $10 \%$ as their fee. Single copies of the January, March, May, October, and November Program issues may be obtained for $\$ 5$ each; the September Directory for $\$ 10$.

Issues for the current year are available from the MLA Publications Center. Claims for undelivered issues will be honored if they are received within one year of the publication date; thereafter the single issue price will be charged.

For information about the availability of back issues, inquire of Kraus Reprint Co., 16 East 46th St., New York 10017. Early and current volumes may be obtained on microfilm from University Microfilms, Ann Arbor, Mich. 48106. Purchase of current volumes on film is restricted to subscribers of the journal.

\section{OFFICE OF PUBLICATION AND EDITORIAL OFFICES}

62 Fifth Avenue, New York, N. Y. 10011 Tel.: 212 741-5588

All communications, including notices of changes of address, should be sent to the Membership Office of the Association at 62 Fifth Avenue, New York 10011. If a change of address also involves a change of institutional affiliation, the Membership Office should be informed of this fact at the same time.

Second-class postage paid at New York, N. Y., and at additional mailing office. Copyright (C) 1974 by The Modern Language Association of America.

Library of Congress Catalog Card Number 12-32040. 


\title{
Contents - October
}

\section{The Raven and the Bust of Pallas: Classical Artifacts and the} Gothic Tale. Patricia Merivale . . . . . . . .

Abstract. Classical artifacts, particularly busts and statues, play an important part as image, symbol, plot element, or even character, in a large number of "Gothic" (i.e., romantic horror) contexts. Eighteenth-century neoclassicism provides "classically" serene artifacts to contrast with "Gothic" ones in, for instance, Poe and Hawthorne. But medieval tradition provides the Venus statue story, where the statue itself is the focus of Gothic horror, in Eichendorff, James, Mérimée, Gautier, and others; this, especially in the subtler artist parables, is the key nineteenth-century usage. For the twentieth century, statues become "Dionysian," classical yet fearful, as in Forster and Lagerkvist. More recently, statues represent a frivolous, melodramatic terror, or else mere emblematic pageantry. In contemporary poetry, however (Rilke, Plath, Seferis), the wheel has in a sense come full circle; classical statues are serious emblems of art and of the artist's obligation to put together the maimed and shattered fragments of a personal and "classical" tradition. (PM)

Friedrich Spee's “Arcadia” Revisited. FredERICK M. RENER .

Abstract. Literary historians and critics from the nineteenth century to the present have attributed Friedrich Spee's descriptions of nature to his personal experience. Except for a few instances of biblical influence, these passages are variations of the topos locus amoenus with many of its less common classical features: the park-orchard-garden varieties of landscape, typical epithets, and catalogs of trees and plants. In the Trutznachtigall, the section with the largest pattern of the topos are the laudes, commonly considered to be derivations of the Psalms, while the eclogues ("Arcadia"), a genre traditionally associated with the topos, has only a few samples of it. Rather than being a rigid formula the topos becomes an elastic pattern whose size and components Spee tailors to the individual poem, providing at the same time a distinct diction and a variety of formulations. This may be one reason why Spee, who is in every respect a poeta doctus, has been mistaken for a Pre-Romantic poet. (FMR)

The Picaro's Journey to the Confessional: The Changing Image of the Hero in the German Bildungsroman. DAvid $\mathrm{H}$. MiLES

\begin{abstract}
From Goethe's Wilhelm Meister through Keller's Grüner Heinrich to Rilke's Malte, the hero of the German Bildungsroman develops from unselfconscious adventurer in the outer world to compulsive explorer of the world within. This transformation in the hero-from "picaro" to "confessor"-implies a change in the concept of Bildung: the "self" no longer accumulates, but must be re-collected. Wilhelm Meister's unreflective nature aligns him directly with the picaresque hero; essentially, he does not develop. In Keller's novel the hero develops precisely by narrating his picaresque past. Through his confessional notebooks, Rilke's hero, Malte, attempts to overcome the "sickness" of his fragmented self by recollecting his childhood. This transformation of the literary hero in the nineteenth century mirrors in turn the historical rise of alienated, self-conscious man. Beyond Malte the Bildungsroman can only move on to parody, to the anti-Bildungsromane of Kafka, Mann, and Grass, in which both types of hero are parodied. (DHM)
\end{abstract}

Purging the Commonwealth: Marston's Disguised Dukes and A Knack to Know a Knave. DAVID J. Houser .

Abstract. John Marston's The Malcontent and Parasitaster, or The Fawne are examined in the light of an analysis of $A$ Knack to Know a Knave (1592). Marston's plays share with the earlier play details of form that involve not only the disguised authority figure noted by critics but also his declaration of purpose, the source and sort of vice he observes, the means by which his discoveries are given expanded significance, and the technique and result of the final exposures. The study of the formal pattern of these elements provides the link between Marston's plays and an earlier example of disguise as the dramatic device upon which the plot turns. The study also clarifies Marston's purposes, in The Fawne to provide a light, satiric survey of the abuses of love and in The Malcontent to analyze with 
greater complexity what is necessary for a virtuous ruler to control a partly corrupt realm. (DJH)

The Personal Element in Dryden's Poetry. Thomas H. FuJIMURA

Abstract. Although Dryden is generally regarded as a public poet concerned with public themes, in the last fifteen years of his life he turned to more private themes to justify himself and his career. We need to be aware of the autobiographical element to appreciate such poems as the "Ode to Oldham," which is not only about a fellow writer but also about Dryden's own achievements as a satirist. The "Ode to Mrs. Killigrew," a Catholic poem, expresses his new awareness of the art of poesy and enacts its ritualistic drama of penance for his "sins." The epistle "To Congreve" is a cathartic expression of Dryden's bitterness as a "cast" poet and of his hopes in a beloved protégé while "Alexander's Feast," by a poet who had just triumphed over many adversities, asserts the poet's power and greatness. These poems are more meaningful if read with awareness of them as personal revelations and affirmations of Dryden the man. (THF)

\title{
Gulliver the Preacher. Everett Zimmerman .
}

Abstract. In his expository writings about religion, Swift suggests that moral fervor is often a disguise for immoral motives. He advises the preacher to avoid any pronounced display of personal qualities in his sermons and to try to eliminate the almost inevitable distortions caused by self-display. In his satires, Swift of ten has his persona say true things for reprehensible reasons. The satire then becomes primarily a study of the moral implications of the relationship of the speaker to his proposals, rather than primarily an incitement to practical action. In Gulliver's Travels the persona presents a view of man's evil that is generally in accord with the traditions of Christianity and of satire. But Swift shows us the immoral intentions of Gulliver; although Gulliver pretends that he wants to reform us, his pretense is a strategy for disguising his own evil from us and from himself. The satiric attack in the book then becomes double; Gulliver satirizes man, and Swift satirizes the motives for Gulliver's satire. (EZ)

\section{The Daemonic in Kubla Khan: Toward Interpretation. CHARLES} I. PATterson, JR.

\begin{abstract}
Despite wide disagreement as to the meaning of Coleridge's Kubla Khan, several recent interpretations point toward what can be formulated by combining (1) Plato's conception of a realm of nonmalicious, daemonic creatures dwelling in unrestricted joy outside human limitations and (2) Plato's conception of the Dionysus-inspired "possessed" poet in a furor divinus as the agent who can in an incantation call up before men the enchanting, terrifying beauty of this daemon world. Suggesting the nature of daemonic beauty and its effects upon people may be a chief aim of the poem, as variant readings in the autograph text indicate. Kubla Khan seems to be a poem about daemonic poetry, a strain that reappears intermittently and thus the search for spiritual and philosophic meanings in the poem could be relinquished. From this point of view, Kubla Khan appears neither as a fragment nor as a poem about evil. (CIP, Jr)
\end{abstract}

\section{Scatology and Eschatology: The Heroic Dimensions of Thoreau's Wordplay. MICHAEL WEST}

\begin{abstract}
Thoreau's puns reflect the widespread philosophic interest in language that flourished in midcentury America. Some of his wordplay is covertly scatological. Though he explicitly defends excrement as natural, philological speculation encourages him to view it as poison. Excremental symbolism bolsters vegetarian ideals and subserves a philosophy where body contaminates spirit. Thoreau's ambivalent anality, evident in his fastidious cleanliness, helps explain his distaste for women, since female biology makes birth unclean and sex dirty. Excremental symbology also colors his view of emotion as a function of the bowels. Unctuous affection seems an oily exudation secreted in social contact, while sympathetic tears are a rendering of the fat accumulated in digestion. His contempt for sympathy as self-indulgent weakness is part of the heroic ethos forced upon him by the consciousness that death tainted his lungs. Dietary scruples are his ascetic strategy for avoiding consumption. Influenced by Wilkinson's The Human Body and Its Connection
\end{abstract}


with Man (1851), Thoreau's covert scatological puns embody in style his philosophy of play, blending estheticism and stoicism in the concept of life as a heroic game. Many nineteenth-century punsters including Carlyle and Nietzsche exemplify similar compensatory attitudes; so do other modern hero-worshipers. (MW)

\section{The Psychological Structure of The Catcher in the Rye. JAMES} BRYAN

Abstract. A number of critics have commented upon Holden Caulfield's "neurosis," but none has accepted Salinger's apparent invitation to a psychoanalytical reading of the novel. As a step in that direction, this paper examines a structural pattern of aggression and withdrawal, largely sexual, in Holden's thoughts and actions. The pattern is reinforced by such characters as Stradlater and Ackley, the former mirroring Holden's mostly fanciful exploitativeness and the latter his more natural tendencies toward retrogression. The episodic middle chapters show Holden vacillating desperately between those tendencies; and the conflict is brought to a curious resolution in the concluding Phoebe section when Holden verges, or rather unconsciously fears he may be verging, on sexual intimacy with his younger sister. The two tendencies converge at that point, and Holden becomes potentially both sexually exploitative and retrogressive. It is this revelation, realized most fully through the writing of his narrative, that points the way to health. (JB)

\section{Pensée rationnelle et responsabilité morale: Le Traité de sagesse} dans La Logique de Port-Royal. MARIE-Rose CARRÉ . . .

Abstract. La Logique de Port-Royal is regarded by historians of this science as a treatise that does not fit into any of their categories; indeed, the art of Logic as an independent exercise of the mind seemed unacceptable to its authors. Writing at the end of the Aristotelian era and under the influence of Cartesian theories, but having their own convictions about man's nature and obligations, Antoine Arnauld and Pierre Nicole saw logical reasoning as justifiable only if it trains the mind to distinguish between Good and Bad. They believed in the existence of an immutable, eternal truth; man's reason is intended to make this Truth a perceivable reality. Logic, most importantly, therefore, trains our word-using and concept-making faculty to acknowledge that the needs of man's soul belong to a much higher order of values than the science of "things": it should thus give reason the strength to be "true" to its own nature. (In French) (M-RC)

\section{Saint-Exupéry, The Myth of the Pilot. JoSEPH T. McKeON}

Abstract. Saint-Exupéry, whether by artistic design or by stylistic spontaneity, wreathes the pilot, the generic hero of his four novels, Courrier Sud, Vol de nuit, Terre des hommes, Pilote de guerre, in an aura of such hyperbole that the reader, raised on the banalities of the "nouveau roman," might find such exaggeration naïve if not ludicrous. Yet the legend of the Saint-Exupéryian hero is not cased in a rigid matrix. In these four works-the first two fiction, the others essentially true narrative-the imagery that forms the substance of the myth of the pilot undergoes a subtle transformation: legendary, mythological, and mystical in Courrier $S u d$, it is subtly and successively altered. In the final pages of Pilote de guerre the metamorphcsis is complete, the myth is dissipated in a profession of fraternal faith, and, through its hero, man is seen in his true perspective, more realistic but no less heroic. (JTMCK)

\section{Céline: L'Itinéraire d'une écriture. PhilipPe AlmÉras . . . 1090}

Abstract. Changes in his expressed ideology subjected the works of Louis-Ferdinand Céline to criteria that were not all literary. Brasillach and Ezra Pound reversed themselves in the assessment of his production; so did liberal and leftist critics. Now, thirteen years after Céline's death, one can attempt a more complete and balanced approach to his works. It must be objective and use a formal angle: statistical analysis along a linguistic and structural line. A study of the vocabulary, syntax, and architecture of Celine's nine novels reveals a continuous evolution. Some changes fall into almost perfectly regular patterns: the fragmented sentence grows to macromolecular agglomerates. In Nord 14 lines are organized in one sentence, while in Voyage they are divided into 17. The overall analysis points up four different periods which do not reflect any ideological changes. Thus, the Célinian novels must be treated as a whole: considered separately, their significance is impaired. (In French) (PA) 
Recollections of Cicognini's Gelosie fortunate in Le Misanthrope. PHILIP A. WADSWORTH

Abstract. One of Molière's early plays, Dom Garcie de Navarre ou le prince jaloux (staged in 1661), was an adaptation of a tragicomedy by Giacinto Andrea Cicognini, Le Gelosie fortunate del principe Rodrigo (1654). Although Molière's work failed, it contained characters, themes, and speeches he revived in his later comedies, especially in Le Misanthrope (1666), where the fourth act contained about ninety lines from two climactic scenes in Dom Garcie de Navarre, confrontations between the jealous hero and the innocent heroine. Molière profited, however, not only from the text of his own earlier play but also from memories of Le Gelosie fortunate, which presented a striking combination of violent emotional conflicts and frequent humorous interludes. It probably inspired some of the excesses of Alceste-his irrational suspicions and vehement language. The Italian source contributed also to the conception and configuration of characters around Alceste, particularly the affectionate and sensible relationship of Eliante and Philinte. (PAW)

\section{Gogol's "Overcoat": The Pathetic Passages Reconsidered.} JUDITH OlOSKeY MILLS

Abstract. Although twentieth-century Formalist criticism has concentrated upon stylistic analysis of "The Overcoat" and its skaz narrative technique, no previous study has focused directly upon another aspect of skaz-the influence of the narrator on the structure of the story and the pathetic passages. This aspect is essential to reconcile the juxtaposition of humor and pathos. The narrator, a creator of fiction, constructs a plot based on a moral principle: excessive self-confidence receives retribution. As evidenced in his tendency to satirize, the narrator is as guilty of this same self-confidence as his characters. Fearing similar retribution, he rejects responsibility for his satiric creation by limiting his omniscient point of view and placing the blame for negative portrayals on his objective depiction of reality. In true skaz style his own attitude, expressed in plot, point of view, and his own pathetic passage, is superimposed on his characters, resulting in the first most quoted passage and in minor variations of it. (JOM)

Forum .

Forthcoming Meetings and Conferences of General Interest . I I 2 I

Professional Notes and Comment

A Commentary on the MLA Directory of Women Scholars and the Status of Women Scholars in Slavic. Alex M. ShANE 


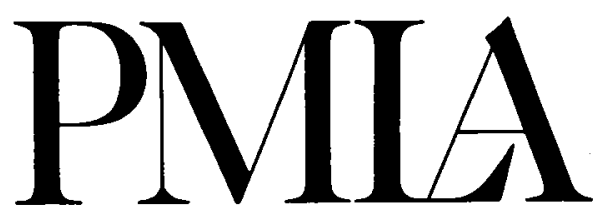

PUBLICATIONS OF THE MODERN LANGUAGE ASSOCIATION OF AMERICA

Published Six Times a Year

Indices: Vols. 1-50, 1935; 51-60, 1945; 51-79, 1964

C. LOMBARDI BARBER

University of California, Santa Cruz

ERIC A. BLACKall

Cornell University

Marcel Marc GutwirTh

Haverford College

HAROLD BLOOM, 1977

Yale University

Paul de Man, 1978

Yale University

JoRGE DE SENA, 1978

University of California, Santa Barbara

ANGUS S. Fletcher, 1978

City University of New York

Stanley Eugene Fish, 1977

Johns Hopkins University

Donald R. Howard, 1978

Johns Hopkins University

JUDD D. HUBERT, 1976

University of California, Iroine

JAMES R. KINCAID, 1977

Ohio State University

RichaRd L. LEVIN, 1978

State University of New York, Stony Brook

William G. Moulton, 1975

Princeton University

\section{EDITORIAL BOARD}

GEOFFREY H. HARTMAN

Yale University

JAMES E. MILLER, JR.

University of Chicago

BRUCE W. WARDROPPER

Duke University

ADVISORY COMMITTEE

Sherman Paul, 1977

University of lowa

Ronald H. Paulson, 1977

Johns Hopkins University

Allen W. Phillips, 1976

University of Texas

ROBERT SCHOLEs, 1978

Brown University

EDWARD WASIOLEK, 1978

University of Chicago

Christof Wegelin, 1978

University of Oregon

THOMAS WhITAKER, 1978

University of Iowa

Nathalia Wright, 1975

University of Tennessee

Theodore J. ZIOLKOWSKI, 1975

Princeton University

Editor: William D. SChaEFER

Assistant Editor: Judy GouldiNG

Promotion and Production Manager:

Senior Editorial Assistant: MARGOT RABINER

JuDith LAPIDUS

Editorial Assistant: JeAn Park

Administrative Assistant: IRENE ZWERLING

\section{A STATEMENT OF EDITORIAL POLICY*}

$P M L A$ publishes articles on the modern languages and literatures that are of significant interest to the entire membership of the Association. Articles should therefore normally: (1) employ a widely applicable approach or methodology; or (2) use an interdisciplinary approach of importance to the interpretation of literature; or (3) treat a broad subject or theme; or (4) treat a major author or work; or (5) discuss a minor author or work in such a way as to bring insight to a major author, work, genre, period, or critical method.

Any member of the Association may submit papers to PMLA. Each paper submitted will be sent to at least one consultant reader and one member of the Advisory Committee. If recommended by these readers, it will be forwarded to the Editor and the Editorial Board for final decision.

$P M L A$ does not normally publish articles of fewer than 2,500 or more than 12,500 words. Articles submitted should be well written and accompanied by an abstract on the standard form obtainable from the Editor.

Manuscripts, prepared according to the second edition of the MLA Style Sheet, should be addressed to the Editor of $P M L A, 62$ Fifth Avenue, New York, New York 10011. Only the original is needed by the editorial staff, but a copy should be retained by the author.

* New Editorial Policy, to which papers submitted after 1 March 1973 must adhere. Papers appearing in the current issue continue to reflect the former policy, for which see any issue prior to March 1973. 